\title{
Passion to Profits: What Makes Royal Enfield Bigger than Harley Davidson?
}

\author{
Rajendra Todalbagi*
}

Visiting Professor, Shri Dharmasthala Manjunatheshwara Institute for Management Development (SDMIMD), Mysore, India

\section{Introduction}

Harley Davidson (HD) is the most well known brand of motorcycles in the world compared to Royal Enfield which is a lesser known Indian brand.

Royal Enfield (RE) sold over 300,000 motorcycles as compared to Harley Davidson's 267,999 motorcycles in the year 2014. An interesting fact to be noted is, just a year ago in 2013, HD dominated the market by selling a 100,000 more motor cycles than RE. RE showed spectacular growth in a span of one year and overtook HD.

RE is owned by Eicher Motors which is India's bus and commercial vehicle manufacturer. Close on the heels of overtaking HD in sales volume, within a year's time on 15th Feb 2016, RE overtook global motorcycle giant in terms of market capitalization too. Two year ago, market capitalization gap was $\$ 13$ billion, and on 15th Feb 2016, RE's market capitalization was $\$ 57$ million higher than HD. (Economic Times, dated 16th Feb 2016)

In this case study an attempt is made to analyze and understand, what has gone behind this business transformation and stellar performance of RE over the last few years and has made RE the numero Uno in the world in mid-size motorcycles market which was on the verge of shut down in the year 2000 owing to mounting losses and no market for their motorcycles.

\section{Company Background and History}

\subsection{Royal Enfield (RE)}

Royal Enfield is an Indian motorcycle manufacturing company with factories in Chennai, India. Originally a British motorcycle company, Royal Enfield and indigenous Madras Motors, it is now a subsidiary of Eicher Motors Limited, an Indian automaker. The company makes the Royal Enfield Bullet, and other single cylinder motorcycles. Established in 1893, Royal Enfield is among the oldest motorcycle companies.

In 1955, the Redditch Company partnered with Madras Motors in India to form 'Enfield India' to assemble, under license, the $350 \mathrm{cc}$ Royal Enfield Bullet motorcycle in Madras (Chennai) to cater to an order from the Govt. of India. The tooling was sold to Enfield India so that they could manufacture components. By 1962 , all components were made in India. The Indian Enfield uses the 1960 engine (with metric bearing sizes), Royal Enfield still makes an essentially similar bike in $350 \mathrm{cc}$ and $500 \mathrm{cc}$ forms today, along with several different models for different market segments.

Royal Enfield was a brand of the Enfield Cycle Company, a British manufacturing firm. After a few years, the company started producing the $500 \mathrm{cc}$ Bullet. In 1990, Royal Enfield collaborated with the Eicher Group, an automotive company in India, and merged with it in 1994. Royal Enfield currently sells motorcycles in more than 50 countries. 


\subsection{Harley Davidson}

Harley Davidson Motor Company was founded in Milwaukee, Wisconsin in 1903. HD is the largest manufacturer of heavyweight motorcycles in the world, and is one of the most identifiable brands in the United States. Harley Davidson is renowned for making one specific product, and is the most recognizable brand in the heavyweight motorcycle industry.

As one of the two major American motorcycle manufacturers to survive the Great Depression, the company has survived numerous ownership arrangements, subsidiary arrangements, periods of poor economic health and product quality, as well as intense global competition to become the world's largest motorcycle manufacturer and an iconic brand widely known for its loyal following with owner clubs and events worldwide as well as a company-sponsored brand focused museum.

Noted for a style of customization that gave rise to the chopper motorcycle style, Harley Davidson traditionally marketed heavyweight, air cooled cruiser motorcycles with engine displacements greater than $700 \mathrm{~cm}^{3}$ and has broadened its offerings to include its more contemporary VRSC (2002) and middleweight Street (2015) platforms.

Harley Davidson manufactures its motorcycles at factories in York, Pennsylvania; Milwaukee, Wisconsin; Kansas City, Missouri; Manaus, Brazil; and Bawl, India and markets its products worldwide.

Harley targets high class customers, and represents success and high social status. Harley Davidson has competitors that make products of the same quality; However Harley is able to charge a premium due to its legendary brand name. Harley Davidson emphasizes the HD riding lifestyle, as opposed to just selling motorcycles. Harley customers are extremely loyal to the brand, and believe that Harley Davidson makes the best heavyweight motorcycles in the world.

\section{Royal Enfield's Business Model}

RE's business model can be termed as a breakthrough emerging market business model with following characteristics.

It has evolved with $50+$ years of experience in automotive space in India.

Pivoted on in-depth understanding of market and customer insights.

Optimal utilization of capital through frugal engineering practices, extensive knowledge of suppliers, operational excellence and global quality standards, efficient supply chain delivering high value to its customers.

\subsection{Business Strategy}

RE has defined its objective as disrupting the existing status-quo globally by creating a new category in motorcycling. Further RE wishes to bring fun and evocative motorcycling focusing on midsize ( $250 \mathrm{cc}$ to $750 \mathrm{cc}$ ) motorcycles. It also redefines motorcycling as a wholesome experience which means owning, riding, caring for and also living with motorcycle.

These machines are simple, lasting and engaging. They are good for all occasions not only for city driving but also for various pursuits like touring, adventure and sporting. Overall these machines are designed to give a complete experience of motorcycle and connect with its customer fully and passionately.

\subsection{Product Portfolio}

RE's range of machines address unique mix of appeals from its traditional customer base to urban aspiration driven youth. While Bullet and Classic are traditional and iconic, Thunderbird, Continental and Himalaya are urban, lifestyle and adventure motorcycles and it looks pretty complete. 


\subsubsection{Bullet}

Bullet 500 marked by the iconic handcrafted design of legendary bullet. It was first launched in 1932. Bullet's association started with Indian Army and has stood the test of times. It is tough and dependable and has earned a bona fide post in automotive royalty. It has thump, pinstripes and road presence.

\subsubsection{Classic}

It retains the classic British styling of 1950s. It is simple, harmonious, proportional and finished well, being made available in $350 \mathrm{cc}$ and $500 \mathrm{cc}$. It has post war styling appeal with power as well as fuel efficiency. The styling is gorgeous and classic too. Its unique beat creates muted feeling of strength and power for which it stands for.

\subsubsection{Thunderbird}

It is a highway cruiser which is specially designed to enhance the pleasure of leisure motorcycling amongst the touring enthusiasts. It is again available in $350 \mathrm{cc}$ and $500 \mathrm{cc}$ variants. Touring enthusiasts form the core of RE customer base. Thunderbird gives them power, comfort and style for long distance travelling.

\subsubsection{Continental GT}

GT is an iconic classic sports motorcycle. This acts as a poster boy of the cafe racing culture. It gives high responsiveness and extra punch required for racers. It is fun, youthful and sporty with $535 \mathrm{cc}$ engine. This has a distinctive style too.

\subsubsection{Himalayan}

This is specially built for exploring Himalayas, which is versatile for riding on and off road. It is a fully ground up design with all new engine with very high touring capabilities. It is powered by LS 410 single cylinder four stroke engine with strong low end torque to clear obstacles and wide usable power to suit variety of terrains and conditions. Himalayan is a fore-runner of adventure touring in India.

\subsection{Royal Enfield's Turnaround and Growth Story}

The entire turnaround and growth story can be classified in to two key phases.

\subsubsection{Phase 1 - Revamp and Reinvent (2000- 2005)}

Redesigning the product, establishing internal processes, listening to voice of customers and brand building, this did set the right platform for changing for good for the company.

The year 2000 was a turning point in the history of RE. Company had decided to either shut down or sell off the loss making RE business. Sales had dropped to 2000 per month against a capacity of 6000 per month and company had accumulated huge losses.

Although motorcycle had fan followers, there were many complaints like engine seizure, snapping of the accelerator or clutch cables, electrical failures and oil leakages. Many found them too heavy and difficult to maintain with gear lever inconveniently positioned and a daunting kick-start.

Mr. Siddhartha Lal, batted for one more chance for RE to turnaround, which board agreed to give and the rest is history.

The bike had its reputation, a cult following, an instantly recognizable build and inspirational value. Changes had to be made to keep with the times and make bike more acceptable, and to attract new customers which had a risk of losing the existing one.

Company did not want to go the commuter market, instead looked at the leisure and life style segment. Some key changes in the product were undertaken while retaining rugged look, including the build, the design of the headlamp and the petrol tank.

Engine : The old cast iron engine, separate gear box and oil sump design made it prone for oil leaks, and it seized up very often, which would also not meet strict emission norms. 
A modern aluminum engine would eliminate all these problems, but would lack old engine's pronounced vibration and beat which was a signature identity. It was not possible to replicate the old, but company went ahead and changed the engine design. The other change was shifting the gear lever to left side from the existing right side which was opposed by diehard fans.

Though it was a high risk proposition to go ahead with these radical changes, company went ahead with the changes viz: designing a new engine and altering the position of gear lever.

Company retained many of the old engine's characteristics like long stroke, single cylinder and the high capacity with push rod mechanism, however with new metal and fewer moving parts. New engine is Unit Construction Engine (UCE) where engine and gear box components share a single casing typically used in larger motor cycles. New engine had 30\% less parts and $30 \%$ more power with better fuel efficiency. All models moved to new UCE engine by 2010 .

Company was facing two other problems viz: quality issue of some components and sales experience of a consumer. 2006 was declared as a year to get back to fundamentals by the company to set these issues right. Company formed field quality rapid action force to bridge the gap between customer expectations and reality. Actions started showing results by 2008 with reduced or almost nil complaints thereby increasing the reliability of the product. Further company launched company owned showrooms to improve the customer experience.

It was all about product planning, process and brand management. Various initiatives under manufacturing excellence and quality have made RE products significantly better proposition. Good power-train, good frame, efficient supply chain, robust manufacturing processes with strong quality systems took RE out of woods. Bold decision of RE management and the leadership of Mr. Siddhartha Lal has paid off rich dividends to company.
Starting with redesigning of engine and creating a solid product portfolio driven by customer needs and having a clear foresight of customer needs and demands has helped RE to grow at scorching pace in the last few years.

\subsubsection{Phase 2 - Branding and Building a Predictable, Scalable Operation for Growth (2006-2015)}

Consolidation and building a stability and predictability across the company and launch of new products to seize the available opportunity for establishing its new revamped image in the market.

\subsection{Strategic Long Term Initiatives}

Following is the analysis of various strategic long term initiatives taken by the company which has put the company on a trajectory of exponential growth eventually, both in terms of sales and profitability with a high degree of operating leverage.

RE's philosophy is to work to transform RE in to truly Consumer first and brand led organization compared to a typical automotive firms led and driven by engineering and manufacturing. RE wants to drive its product engineering and manufacturing decisions based on their consumer need and the trend consumer would like to follow and where the company wants to take its brand. RE has set out an investment outlay of Rs 600 Crore for setting up state of the art technical centers, new product development, adding manufacturing capacity and market development activities across geographies.

\subsubsection{Product Strategy}

Over the years, company's growth has been driven by design and development of products that are true to the brand ethos of RE Brand. Designing and developing evocative and exciting products is central to the company's future strategies. In order translate its long term growth objectives in to reality; company has laid out an elaborate roadmap for developing new generation platforms and products. 
In May 2015, RE has acquired the brand, technical know how, intellectual property and the business of UK based Harris Performance Products Ltd., which is one of the leading experts in the space of designing, manufacturing and marketing motorcycle chassis and components. RE had a longstanding relationship with the company before acquisition.

HPPs deep knowledge and expertise in motorcycles is invaluable for company's product development journey and augments the company's capabilities instantaneously.

RE has also started building two technical centers one in India and other in UK. These centers will be shot in arm and help the company keep ahead of the curve on technology and product development and build intellectual property. This will also enhance the ability to attract the creamy talent pool in India as well as globally. These centers are going to be equipped with state of the art testing and validation infrastructure too.

\subsubsection{Sales, Marketing and Branding}

Company has rolled out a differentiated retail experience to its customers through various initiatives. RE has defined its innate philosophy of "PURE MOTORCYCLING" for its unified global retail identity. This unique identity has been rolled out to RE stores in India and its exclusive stores in international market. This retail format has drawn inspiration from its brand philosophy of creating an ambience similar to what could be found in the living room of an avid motorcycle enthusiast.

The new face of RE's stores have created a benchmark in motor cycle retail. New retail identity extends itself to every aspect of RE ownership experience. The service centers are also designed on same lines.

Building aspirations globally: RE's belief is that potential of global market for the midsize $(250 \mathrm{cc}$ to $750 \mathrm{cc}$ ) motorcycles is many times its current size, with upgrading customers in emerging markets and more urban customers in mature markets. RE with its evocative and engaging products is very well placed to catalyze the shift to midsize motorcycles in Latin
America and South East Asia, where motorcycles are popular means for city commuting. RE community and engagement activities: RE organizes and supports many motorcycling events and rides like Rider Mania annual gathering from all over India, One ride - where people around the world ride out on their motorcycle on first Sunday of April.

International market strategy: Having seen huge opportunities in international markets, company is executing geography specific long term and sustainable strategies to achieve growth. RE has changed strategy for North America by setting up 100\% subsidiary and ended distribution through dealer to give a special impetus and attention to the market. As part of RE's city led approach, the brand has set up twelve exclusive stores in key international cities. Those are five in Colombia, two in London and one each in Bangkok, Dubai, Jakarta, Madrid and Paris. These exclusive stores will play a major role in establishing the brand in these markets and give a foothold for sales, marketing and riding initiatives of the company to build motorcycle enthusiast community.

The Brand retail identity rolled out in Indian market is implemented in international markets as well.

\subsubsection{Supply Chain Strategy}

RE through its supplier rationalization has consolidated its supplier base and brought in best in class supplier partners and worked closely with them in improving efficiency and quality. Company has implemented and practicing various lean manufacturing techniques to take away wastages by eliminating or rationalizing non-value added activities and processes. Company has reduced its inventory holding from thirteen days to nine days in the last six years. It has achieved a cost reduction with respect to input materials by $9 \%$ and rationalized its supplier base from 247 to 166 (more than $30 \%$ reduction) over the last five years. These have improved operating efficiency and taking the company towards operational excellence. Thus it has helped company to achieve very high degree of operating leverage resulting in to exponential growth in profits. 
Company is also building additional capacity with the construction of third plant which should be commissioned by later part of FY18. RE's production capacity is expected to hit 900,000 motorcycles annually by FY19.

\subsubsection{Manufacturing Strategy}

RE started its production at its second manufacturing facility at Oragadam in Tamilnadu. State of the art facility was commissioned in April 2013. This plant has been instrumental in achieving scale and high quality standards for its products. This new plant is expected to contribute in achieving a planned production of 675,000 motorcycles in Fy17.

New plant has helped RE to scale in many ways like cost optimization through low cost automation, new cathode electro deposition (CED) paint shop, robotic painting system, powder coating system, ergonomically sound new vehicle assembly line, torque controlled tools with feedback device which allows production of one motorcycle a minute and re-tooling of parts to achieve precision and finish coupled with robust IT infrastructure which works as strong backbone for the production processes in the manufacturing plant. Plant is also designed keeping in mind environmental health and safety making it a green manufacturing plant.

\subsubsection{Human Resources Strategy}

Company's performance is directly dependent upon the knowledge, skills and competency of its people, and their ownership of organizational and functional objectives. This needs to be supported by right environment with motivation and enthusiasm leading to performance and people taking pride in their work. Company has continued to hire and deploy resources in international locations as part of international growth strategy. RE also continued to align its organizational structure with its three year strategic business plan for enhanced effectiveness. Company has simplified and automated all people processes and implemented on-line systems to manage people processes effectively. The attrition has remained below $6 \%$, which is a reflection of engaged and committed workforce. Company has strengthened its brand building and product development capabilities through strategic hiring at leadership level, which has brought its President Mr. RudraTej Singh from FMCG giant Unilever in Jan 2015, appointed Red Copes a former Harley Davidson Manager as President, RE, North America and Pierre Terblanche as head of Industrial Design who has joined from Ducati also hired best in class global talent for its Design centers.

Launch of classic model in 2009 and transforming the whole portfolio to UCE engine drove growth in sales. Annualized growth from 2006 to 2010 which was at $10 \%$ shot up exponentially to $54 \%$ in the next five years when all the initiatives started paying off.

Leveraging on the homework done over a decade, company grew its market share and overall sales in an exponential manner and created a huge value for all its stakeholders.

\subsection{Industry Structure, Market Size and Market Share}

Motorcycle industry was flat in FY 16 over FY 15 and size remained at 107 lakhs for both the years. In the previous year FY 15 grew by 1.9\% over FY 14.

However RE's market share has grown from $1.9 \%$ in FY 14 to $4.7 \%$ in FY 16. So RE has outperformed industry growth as it has been doing over the last several years.

Motorcycle industry can be classified broadly in to two categories viz: $150 \mathrm{cc}+$ engine displacement segment and $250 \mathrm{cc}+$ engine displacement segment.

150cc and above segment has grown from 17 lakhs to 22 lakhs from FY 14 to FY 16 by 29\%. RE's market share has grown from $12 \%$ in FY 14 to $22.2 \%$ in FY 16.

250cc and above has grown from 2.18 lakhs in FY 14 to 5.19 lakhs in FY 16. RE's market share has grown from 93\% in FY 14 to $96 \%$ in FY 16 and RE has monopolized the segment practically with no competition. 


\subsection{Business Performance}

During FY16, RE sold 508,099 motorcycles which is six times of what it sold five years ago with a total market share of $96 \%$ in midsize (250cc to $750 \mathrm{cc}$ ) motorcycles segment. It also achieved an EBITDA margin of $28.3 \%$ which is a benchmark in automobile industry.

With more than five lakh of motorcycle sales in FY 16 , RE has registered annualized growth of $56.14 \%$ in comparison to FY 14 sales of two lakh plus motorcycles. In the same period international market grew at $16.4 \%$ over FY 14.

Revenue for FY16 was Rs 5226.87 crore with an annualized growth of $61.5 \%$ over FY14 (Rs 2004.4 Crore) and profits grew faster than sales from operations in the same period with a very high degree of operating leverage. EBITDA for FY16 was Rs 1497.28 Crore with an annualized growth of $91.9 \%$ over FY14 (Rs 401.49 Crore). EBITDA has grown from $20 \%$ in FY14 to $28.3 \%$ in FY 16 .

Revenue from parts and services grew to Rs 404.82 Crore in FY16from Rs 167.01 Crore in FY14 registering an annualized growth of $55.7 \%$ over FY14.

Revenue from International market grew to Rs 159.82 Crore in FY16 from Rs 90.62 Crore in FY14 registering an annualized growth of $32.8 \%$.

RE's long term goal is to lead and grow underserved global midsized motorcycle segment thereby emerge as a dominant player in the global midsize $(250 \mathrm{cc}$ to $750 \mathrm{cc})$ motorcycle market.

RE continues to clock a blistering growth in all aspects, market share, sales and profit. Company currently enjoys a dominant position in $250 \mathrm{cc}$ and above segment in Indian market with a market share of $96.1 \%$.

Company has been focusing on growing international markets. Its global strategy combines its learning from India success and is calibrated for specific international geographies.

With a commanding market share of $96.1 \%$, RE can grow by expanding this market. $\mathrm{RE}$ is executing many long term strategic initiatives to further expand the market, like focused marketing programmes, network development and new product launches.

Various long term strategic initiatives taken by the company in the last five to ten year time frame have yielded spectacular results over the last few years.

\subsection{Recognition Awards and Accolades}

Eicher Motors has won following awards as an endorsement to its outstanding performance.

Emerging Company of the Year at the Economic Times awards for Corporate Excellence 2015

The Best Company of the year at Business Standard Annual Awards 2015

Company's MD \& CEO Mr. Siddhartha Lal is also conferred with following awards.

The NextGen Entrepreneur, Forbes India Leadership Award

India Best CEO \& Best CEO, Business Today, Mind Rush Awards 2015

Best MD\&CEO (2- wheelers), the 2015 World Auto Forum Award

\section{Conclusion}

Critical to successful turnaround has been a strong and passionate leadership with a clear vision and focus with bold decisions to reinvent the company in every aspect to make it a robust growth engine. This has been further supported by strong business strategy with Customer first and Brand building to create a traction in the market and unique customer experience for motor cycle ownership. Company has made a big time investment to build capabilities in product design, state of the art 
manufacturing facilities, retail format and best in class global talent from the industry with a clear focus and long term goal.

\section{Author's Note}

Royal Enfield is an excellent case on business turnaround, where all hopes were given up and the management was about to call it a day and wind up the company to cut further losses.

The case demonstrates how a leadership with vision and appropriate strategies with careful execution can create a winning and thriving business from a hopeless situation. Today RE has come to a global reckoning even surpassing the world leader in two wheelers market, Harley Davidson.

Back in 2000, you name it, everything was broken inside the company like a cacophony and company was in deep red. It is the passionate visionary leadership of Mr. Siddhartha Lal and coordinated well thought out business strategy leading to various functional strategies and successful implementation over a decade has helped company to emerge as a phoenix.

Holding on to a single thread of the cult following and keeping customer at the center stage, company was practically reinvented and rebuilt on all aspects right from redesigning and reengineering product platform, revamping the product portfolio, internalizing excellence in operations and quality, creating and building a strong brand, developing an ardent community of customers and providing a unique experience of owning a bike than buying a bike which was all enabled by acquiring and nurturing the right human capital and leadership across functions.

As a result of carefully crafted strategy and meticulous execution, company is enjoying a special place in its own identified market segment of midsized motorbikes ( $250 \mathrm{cc}$ to $750 \mathrm{cc}$ ) with a market share of more than ninety percent and an operating margin of more than twenty-eight percent and very high degree of operating leverage which lends the company an enviable position.

\section{Teaching Notes}

For the purpose of initiating and directing discussions in the classroom the following pointers may be used by the instructor with regard to the case:

- How to develop various functional strategies like sales and marketing, operations, human resources and financial which are complimentary to each other leading to a successful business strategy and value creation to all the stakeholders?

- Can we analyze this case from the "Balanced score card (BSC)" framework?

- Discuss the challenges involved in developing a business strategy in a continuously changing business environment and executing it successfully to take a company out of woods.

- Discuss and evolve a generic framework for turnaround of a company.

- Discuss the impact of leadership, vision and strategy in the ongoing success of businesses.

\section{Bibliography}

Retrieved from https://en.wikipedia.org/w/index.php?title=Royal_ Enfield_(India)\&oldid=743038019

Retrieved from https://en.wikipedia.org/w/index.php?title= HarleyDavidson\&oldid $=742814064$

Retrieved from http://www.businesstoday.in/magazine/casestudy/reviving-royal-enfield-bullet/story/19892.html

Retrieved from http://economictimes.indiatimes.com/industry/ auto/news/two-wheelers/motorcycles/meet-siddhartha-lalthe-man-who-turned-around-royal-enfield-into-eichermotors-profit-engine/articleshow/46461712.cms

Retrieved from http://www.exchange4media.com/marketing/ royal-enfield-profits-up-by-33-compared-to-harley-davidson-in-2015 63595.html

Retrieved from http://www.indiatvnews.com/buzz/tech-auto/ why-royal-enfiled-is-better-than-harley-davidson-34.html

Retrieved from http://www.enidhi.net/2014/12/royal-enfieldbullet-hate-love-never-buy.html

Retrieved from http:/timesofindia.indiatimes.com/business/ india-business/Royal-Enfield-races-past-Harley-Davidsonin-global-sales/articleshow/46090462.cms

Retrieved from http:/www.forbes.com/sites/saritharai/2015/02/ 18/indias-vintage-royal-enfield-overtakes-harley-davidson-by-motorcycle-sales/\#31bb5dc87f2b

Retrieved from http://indiaautoreport.com/royal-enfield-fasterthan-a-bullet/ 
Retrieved from http://www.rediff.com/getahead/slide-show/ slide-show-1-biking-and-motoring-the-amazing-storiesof-harley-davidson-and-royal-enfield/20120714.htm

Retrieved from http://economictimes.indiatimes.com/markets/ stocks/news/eicher-races-past-harley-davidson-on-m-capstreet/articleshow/51003552.cms

Retrieved from http://overdrive.in/news/analysis-royal-enfieldis-now-bigger-than-harley-davidson/

Retrieved from http:/www.ianwatsonsdrivingschool.com/ blog/2016/1/13/the-royal-enfield-a-closer-look-at-theiconic-motorcycle

Retrieved from http:/www.eicher.in/uploads/1473226230 eicher-Q1-FY17-investor-presentation.pdf

Retrieved from http:/www.eicher.in/uploads/1455538656 eicher-investor-presentation-february-2016.pdf
Retrieved from http://www.eicher.in/uploads/1466253126 eicher-annual-report-2015-2016.pdf Retrieved from http://www.eicher.in/uploads/1427358485_Downloads AnnualReports_AR2K14.pdf

Retrieved from http://www.eicher.in/uploads/1410247134 Downloads_AnnualReports_AR2013.pdf

Retrieved from http://www.eicher.in/uploads/1410247336 Downloads_AnnualReports_Annual_Report_2012.pdf

Retrieved from http://www.eicher.in/uploads/1450092785 royal-enfield-supply-chain-and-manufacturing-excellence-by-b-govindarajan-coo-royal-enfield.pdf

Retrieved from http://www.eicher.in/uploads/1450092785 royal-enfield-in-north-america-first-operating-direct-distribution-rod-copes-president-re-north-america.pdf

Retrieved from http://www.eicher.in/uploads/1449031031 eicher-27-11-2015.pdf 